\title{
AFRICAN LITERATURE TO-DAY
}

Being interested in African literature one seems to swim from the very beginning in a terminological maelstrom. What is African literature? Is it literature written by any African author in any language? That would mean approaching the question from a purely racial basis. It would imply the art of demonstrating that any piece of such literature could infallibly be recognised as African, a thing which, as far as I know has never been done. Or is African literature strictly bound to traditional African culture?

A combination of the racial and the cultural approach to African literature on the basis of cultural anthropology was tried and practised with fair success by the German author Janheinz Jahn in his books "Muntu" - first published in German in 1958 and later also in English - and in "History of Neo-African Literature" (Eugen Diederichs, 1966). Jahn thought in non-racial terms in so far as he exluded from African literature African writers who had wholly assimilated to a Non-African culture such as for instance the Portuguese Black writer Alfonso Alvares of Evora who lived in the 18th Century. On the other hand, Jahn thought in terms of race when he excluded from the range of African literature African Whites such as the Afrikaners, but included South African Coloured writers. Jahn's starting point was the literature of the American and West Indian Negro. From there he looked to Africa in much the same way as the poets of the Negritude had done, and he tried to standardise African literature according to a scheme of cultural values - "Wertkategorien" - taken from Alexis Kagame's Bantu philosophy and from the linguistic structure, that is to say, the noun classes of Bantu languages. Therefore the title of his fundamental work "Muntu" - "human being", representing the first noun class (mo-class in Sesotho, umu-class in isi-Zulu and so on). Jahn thought to have found in this way the clue to literary Africanness, unifying Black authors of Africa and the Americas, inclusive of West India. Because this literature had undergone the impact of Colonialism and Westem civilication he called it "neoafrican", differentiating it hereby from the traditional literature of precolonial Africa. A differentiation which looks to me somehow arbitrary, as a certain degree of Non-African influence, an amalgamation of 
various cultures, can easily be traced in oral African literature as well.

I could make another observation with regards to Jahn's cultural approach. He standardized African literature in terms of cultural values by saying that literature must have such and such characteristics in order to be classified as African. He disqualified all literature which did not harmonize with his concept of cultural values. This happened when he called the early literature of South African Bantu writers "Zöglings" - literature, pupil's literature. He would not allow African literature to be Christian in its essence. The same reverve should have been made, if we follow Jahn's concept, towards certain African authors who have grown up in cities and have fully turned to materialism. Jahn's view is an idealistic one. Whatever does not fit in to his idea of Africanness does not qualify to be called African literature. Richard Rive, one of South Africa's Coloured writers, says in "Contrast" no 11 ( $p$ 67): "To expect a literature that is essentially African which is unique in its Africanness, is to deny the many differences in the African experience, the many and varied factors at work, from which the true poet assimilates the best and fashions it as an instrument of his own."

\section{LANGUAGE}

Another way of approaching African literature could be through language, limiting its range to the home-bred African languages. Of approximately 500 spoken African languages about 70 have been used for literary purposes. However, on this understanding, literary works written by African authors in English, French, Portuguese, Arabic would not belong to African literature, but from part of English, French, Portuguese, and Arabic literature respectively Here we must be careful and incidentally give way to Jahn's view. I have found that linguistic structures forming part of - speaking in terms of Jahn - "cultural values" may indeed be identified in certain works of African authors written in Non-African languages. Such influences are revealed either in style or literary structure. To become aware of something very African let us think for instance of the trend to reduplicate and repeat, or of the peculiarity of using abstracts and impersonal nouns as subjects in the place of persons. The latter happens when Amos Tutuola (Nigeria) in one of his English works, "The 
palmwine drunkard", makes laughter itself laugh, in the very same way as the South Sotho author Thomas Mofolo, in his novel "Pitseng" (written in Sesotho) lets the act of whining itself whine. Mofolo writes : "Eare ha ba etamela kereke, ea lla mòllo òsele-sele, ea lla e bolela tsa thabo e fetiseng", meaning "When they approached church, a very strange whining whined, it whined and spoke of exuberant joys." And to take an example of an impersonal but concrete noun, I may quote Tutuola saying in "My life in the Bush of Ghosts": "I stopped there and asked myself this question: Can land talk like a human being or can land find pain if somebody smashes it ... so without hesitation I jumped unto this talking land .... then it started to speak as before ...." (p 85).

Returming to our question of whether African literature is to be limited to African language, I should say, no. Literature by African authors in Non-African languages may indeed form part of African literature. We cannot but take into account the intrusion of linguistic and cultural Africanisms into such literature. I have deliberately said : the intrusion of linguistic and cultural Africanisms, for not every Africanism is due to language. The fact that Chinua Achebe and other Ibo writers turn oftern to accumulations of seemingly incoherent proverbs, has not to do with style. It is not, say, "a stylistic mannerism", which might appear in Non-African prose just as well as in an African novel. Nor could it be explained in ordinary language terms such as "African languages abound with proverbs." For a full explanation we must rather return to proverbial speach in particular circumstances, as for instance, when a wish has to be outspoken which, for decency or expediency may not be expressed directly but by means of proverbs only. So the argument for Africanisms in English prose of African authors will have to be found in this particular case in the field of cultural anthropology, not of language.

\section{GEOGRAPHICAL POINT OF VIEW}

Having thus made a step towards the cultural and the language approach, I still feel dissatisfied. How would you classify African authors who have fully accepted either the Christian or the materialistic way of thinking or authors whose language and style in no way show Africanisms at all, 
but who, as social beings, participate in their African community? Reading authors such as Ferdinand Oyono and Mongo Beti from the former French Cameroons, or Camara Laye from Guinea it might be difficult to trace Africanisms in language and style, yet, on reading their novels, we vaguely feel something, not easy to define. We may call it mental climate, atmosphere, surroundings, a factor which is formed by any possible aspect of background, a factor which is revealed in problems and motives as well as in the way these are handled and accentuated. I would call this factor "African" and hereby determine African literature from a geographical point of view. In my opinion geography, inclusive of the aspects of biological, socio-political, cultural and last but not least, historical background is most important in limiting the range of African literature.

When reading West Indian authors, Jacques Roumain, Aimé Césaire, after having read African authors such as Thomas Mofolo, Bennet Wallet Vilikazi, Yosia Ntara (a Rhodesian author), Ferdinand Oyono, I strongly felt the distance between two worlds, between the literary scenes of the WestIndies and Africa. The Caribian literature is to me nearer to expressionism, than the African. It shows a type of fictitious passion alien to the more realistic passion of Africa, and a higher degree of adaption to the literary feeling of the Western world; it is in a way "weaker", more selfconscious and less self assured than the literature of Africa-born authors. I still think my first impression is to the point, and if you were to ask me how the difference is to be explained, I would answer: the historical and the socio-political backgrounds of the West-Indies and Africa differ substantially from each other. The West-Indians were expatriates from the very beginning of their "history". When the intellectuals started writing, they at first did not want to be recognised as Coloured authors and later, when they outgrew their dependent state of mind, they felt like expatriates looking with a romantic eye for their lost Africanness. That was the origin of "négritude".

As for the Africans, they never wholy lost their background, they never were expatriates: they felt at home in Africa and had not had to search for it. They were always in the 
majority and, even when being confronted with Western civilisation and when they became aware of their material backwardness, they had no reason for feeling exiled or weak. They had lost neither their social personality nor their Africanness. Both were consciously or súbconsciously present in their group solidarity.

Concluding the terminological exposition I would say : African literature is literature written in African or Non-African languages by authors who live permanently in Africa, who have no other homeland than Africa, whose personality has, among other factors, been formed by. Africa. Afrikaans literature forms, in my opinion, part of African literature. The literature of the American Negro and the West Indian has a secondhand character: it has to do with African literature in much the same way as the literature of the Renaissance had to do with the literature of classic antiquity. On the other hand works written by North Africans in Arabic may form part of African literature, in so far as they grow out of the African context and do not show alien products of an imported culture. The same applies to works written in European languages. We may speak of African literature in the same way as we speak of Australian, American or Latin-American literature, with the difference that here we have to do with one or two languages whereas Africans speak in about 500 languages and publish in over 60 .

My point is as follows: I say "no" to a racial limitation of African literature. I say "yes" to the limitation on the basis of culture and language; I say "no" to the expansive consequence of the cultural view, resulting according to Janheinz $\mathrm{Jahn}$, in the idea of an all-embracing "neo-African-American" literature. I try to locate African literature within the borders of the African continent, excluding only those items which are imported wares and thereby essentially alien to A frican surroundings.

\section{HISTORICAL SURVEY}

After this terminological lay-out I shall try to give a short historical survey of the language situation. In doing so I shall concentrate on the literature of Black Africa, thus wittingly excluding litetature by South African Whites or other Whites living permanently in Africa. 
Fiction writing in Africa by Africans started in the beginning of this century in Lesotho (with Thomas Mofolo); West- and East-Africa followed a decade or two later. But the high-tide came after the 50's, with a flood of mainly prose writing mainly in French and English. Nevertheless, the production in African languages should not be underrated. Seen in figures, Amharic and the South African Bantu languages proved most prolific, with more than 400 literary works in the 7 Bantu languages of South Africa up to 1970, according to Jahn's Bibliography of African writing (1971), and 200 publications in Amharic, On the top of all Subsaharan African languages, is the language of the small Lesotho (Sesotho) with more than 100 items, followed by isi Xhosa and Kisuaheli. In West Africa, Yoruba (Nigeria) and Otwi (Ghana) are leading but still figuring below two further South African languages, Isizulu and Senedi.

There are new literary trends which can be followed up throughout Africa, whether in African or Non-African languages. For instance, the trend of African authors to identify with African history. In East-and West-Africa the more recent past before and after 1950 has been made already the subject of literature. I mention the epic work of the Tansanian writer Shabaan Robert on World War II in Swahili, "Utezi va vita vya Uhuru ...", and the prose trilogy "Harmattan" by the Senegalese auther Sembeno Ousmane, dealing with the period since 1958. Furthermore, writers of East and West and South Africa show interest in colonial and precolonial history. I think of Ebrahim Hussein (Tansania), who treats the Maji-Maji-upheavel under German colonial rule in a play "Kinjekelile", or of the Ethiopian dramatist Tsegaye Gabre Medhin, interpreting in "King of Kings, Tewodros of Ehtiopia" the British victory at Meqdela in 1868. "Kurunmi", a play by Olawale Rotimi in Yoruba (Nigeria) concerns the Ijaiye wat which took place in the 19 th century, whereas the novel "Le devoir de violence" for which the Mali author Yambo Ouologouem received the Prix Renaudot in 1968, analyses the period of French colonisation. A Zulu author, Kenneth Benghu, follows the line of the historical novels by his countrymen Rolfes $\mathrm{R} R$ Dhlomo and Bennet Wallet Vilikazi. Amongst the Basotho several authors present the founder of their nation, King Moshoeshoe I. We may mention in this respect, L E Mahloane, Thomas 
T Mofolo, son of the famous author of "Chaka", and Atwell Sidwell Mopeli-Paulus. The grand old time of the Zulu too is resumed, for instance in a drama by Pius $J$ Hlelele, a Masotho author. In Rhodesia Lawrence $C$ Vambe, a member of the Shona people, creates in "An ill-fated people - Zimbabwe before and after Rhodes" (1972) an atmosphere as we know it already from the historical novels by the South African Coloured author Peter Abrahams, or in Solomon Tshekiso Plaatje's novel "Mhudi".

In contrast to the somewhat romanticising outlook of these last mentioned novels, a new sense of historical realism seems to have developed recently in the literary works of West- and East-Africa. A new apprehension is breaking ground, that colonialism is not bound to any particular epoch, nation or race but may grow anywhere at any time. As early as 1963 we read with Tsegaye Gabre Medhin, that the British were not the first colonialists, nor likely to be the last. In one of Ellis Ayitey Komey's stories, published in an anthology, "Modern African Prose" (1964), a Limey (British) a Yankee (American) and a "Red one" who speaks English with the accent of Radio Moskau", venture to flirt with an African barmaid. The girl, "mentally rich, and pure had found already her way in the dark." She therefore turns her back on all three of her wooers. Here we still sense the romantic tinge of négritude, but at the same time the second step towards a reassessment of colonialism is done: the same measure is now applied to British, Americans and Russians. The Mali writer Yamboo Ouologouem goes one step further He was, as far as I know, the first African writer who, in "Le devoir de violence" (1968) applied the term Colonialists to Non-Whites, to Arabic slaveholders and even to African potentates. In this novel traditional as well as modern Africa perpetrates horrid brutalities. The négritude-dream of the noble African soul has gone. Ouologouem, however, does not slander any nation or race. He rather seems to elucidate the antithesis of spirit and a sort of aggressive conformity, a conformity of mind ever falling back in to sadism and terror. Ouologouem's problem is the isolation of the African intellectual and his conflict with his society, and old theme in African literature. I have but to mention in this connection Herbert Dhlomo's epic poem on the "Valley of a 
Thousand Hills", published in Durban in 1941. Above all we see, however, in works with a trend such as it shows in "Le devoir de violence" Africa's disillusion of decolonisation. The Gambian poet Lenrie Peters gives the shortest version of this new insight into African history, when he says?

"We starved as slaves, colonials, then home-made slaves again".

\section{SELF-CRITICISM}

The late sixties and early seventies have brought a striking novelty to African literature: the awakening of African self-criticism. The experience that the world between African tradition and civilisation is a world upside down was already being expressed by African authors all over Africa in the fifties. Think of Mongo Beti's novels "Ville cruelle" and "Le pauvre Christ de Bomba", of Ezekiel Mphahlele's short stories "Man must live" and so on. The reason for this chaotic state had, however, always been seen in the impact of colonialism and White civilisation on Africa, an argument which refers even to the authors whom I think to be the most circumspect of all - to the Ibo, Chinua Achebe, in his first novels "Things fall apart" and "No longer at ease." But with "A man of the people" (1966) also by Achebe, and with Wole Soyinka's play "Kongi's harvest" (1967) - Soyinka is yet another Ibo writer - a wind of change was blowing. For the first time a literary attack was launched against political leaders of postcolonial, independent Africa. An attack which went on and has so far reached its climax with Ayi Kwei Armah's novel "The beautiful are not yet born" (1968) describing life in Ghana immediately before the overthrow of Nkrumah's government. Again, as in "No longer at ease" an employee of the lower class is confronted with the allembracing corruption of a postcolonial African society. But whereas Achebe's petty chap - after drowning in the mud of bribery - is finally prosecuted along the lines of the new society, Armah's railway employee, on the contrary, shows the big leader in his flight from the persecutors the way to freedom in a very drastic sense: the big man of the people escapes through the closet tube in the house of the small employee, who once was his schoolfellow. Rottenness and filth on the one hand and purity on the other form the 
antithesis in Armah's novel. Even the new teachers of Africa, Mao and Castro, get involved in the timeless process of putrefaction. The petty employee lives in moral cleanliness against his better judgment that, as Armah puts it, "in these times honesty could only be a social vice for the one who chose to indulge in it, nothing but a very hostile form of selfishness, a very perverse selfishness". With nearly the same words the Senegalese auther Sembene Ousmane characterises the situation in "Le mandat" (a radio play, 1970) in which a labourer has the expireence that the world is full of wolves; that "I'honnêteté est un délit de nos jours" (that honesty is a vice nowadays). In Oumane's novel "Vehi Ciosane" (1965) there had already been many facts about race solidarity of Black Africa not hindering the illegal doings of African potentates, and with Armah this experience cristallises in the words: "Now another group of bellies will be bursting with the country's riches". Gone is négritude's song on African democracy overthrowing despotism and tyranny, for, as Armah says, "when the coup took place, people were talking, but in truth nobody knew anything except that there had been a change ..." Dethroned also is the other idol - African socialism (the term reminds us of a famous book by Léopold Sedar Senghor) for, speaking of socialism, Armah writes: ". . . . and yet these were the socialists of Africa, fat, perfumed, soft with the ancestral softness of chiefs who have sold their people and are celestially happy with the fruits of the trade . . ( $(\mathrm{p} \mathrm{180)}$. And the big ones floated free, like all slogans . . . Build socialism, equality ..."

And finally what about the African personality's "love for peace?" The Nigerian play wright Obotunde Ijimere in "The imprisonment of Obatala" confronts the God of war with the God of creation. Both stand on the same level. They are equal to each other. Peace and war are supposed to form a unity in the same way as do life and death.

Criticising the new political elite proves to be a literary trend all over Africa. A few names and titles may stand for this: Sarif Easmon (Sierra Leone) caricatures the African politicians in his three-act play "The new patriots" (1965). In "Wind versus polygamy" (1964) Obi Benue Egbuna from Nigeria terms politicians "a bunch of Europeans in black 
skin." In Cameron Duodu's novel “The gab boys" the young rebels in gabardine trousers direct their attack against people whose acts appear to them the aping of the defeated imperialists. And Armah says: "There is no difference at all between the white men and their apes . ..., our party men." A similar animosity against the leaders of postcolonial Africa is to be felt in East African literature. I mention Wilson $\mathrm{K}$ Mativo, "Our true speakers", and David Rubadiri, "No bride price" (1967); Okot p'Bitek of Uganda chastises in the name of tradition the new political intelligentia, when he says in his epic "Song of Lawino": "Tell me, you student of communism/ and you professor of history/ Did Senegalese blood/ Flow in the veins/ of Karl Marx/And Lenin/ Was he born/ At Arusha?"

Gone is the tide of raving for and palavering about -isms and party ideologies. One has become more realistic. Africans, Armah tells us, are now "in fear to hear the farts of the Party men." And p,Bitek joins him with his argument that the Africans applaud their leaders only in order to rise above the noise they make. Wole Soyinka (of Nigeria) lances another attack on the brutality of African leaders in his "Jero plays" of 1974. Yet there still remains residue of the well known African cheerfulness combined with passion, of laughter mixed with crying. I think for instance of the tragicomic character of the old Chief in Ahmadou Kourouma's (Ivory Coast) ironical novel "Les soleils des indépendences." After having fought for independence, the former chief is imprisoned and tortured by representatives of the new government. A friend manages to gain his amnesty against his will. When the ex-Chief wants to re-enter his territory, he is hindered by the soldiers of the new regime. "Damnea colonialism! Damned independences!" he says, meaning hereby: the only independences are the personal freedoms of the new potentates in modern Africa; independence as such, however, freedom - uhuru, for which he fought, does not exist.

The Nigerian Civil war is of special interest within the political views expressed in recent literary works of Africans Wole Soyinka and Christopher Okigbo first put down their forebodings of war in poetry, publishing "October 1966" and "Path of thunder". Thereafter an allegorical play, 
"Madmen and specialists" which Soyinka had written during his imprisonment appeared. It tries to testify that in war bigger damage is done to the winner than to the loser. Soyinka thinks of damage done to man's soul. In a similar way John Pepper Clark deplores in his poems "Casualties" the psychological effects of war.

"We fall all casualties of the war because we cannot hear each other speak. .."

In his short stories "Girls at war", Chinua Achebe looks for the reality of war. He regards war as a wrestling-ground for many people who are searching in it for personal satisfaction; he sees war in its absurdity, its disintegrating results, but also as an experience for the will of survival.

So here too, in the field of war as in the field of African politics, a sense of psychological realism is winning ground. To disillusion in politics and - as regards Nigeria - disillusion in military affairs, is to be added disillusion and demythologising in matters of civilisation and technical progress.

Technology had once been made the subject of animistic belief, in street songs of the Bantu as well as in folkore novels such as Amos Tutuola's "The Railway". The electric bulb, the radio or any other technical achievement which for us has become a pure banality, was raised in the Black man's mind to the level of a subject purporting its own mystery and magic. Now, spiritually dethroned, they appear in much the same way as the politicians do. In Ethiopia Abbé Gubänna in his three-act verse play "The savage girl" (1964) attacks civilisation for being "inhuman", whereas Cameron Duodu of Ghana speaks in a depreciative way of machines and of what they do to man. "Our ideals are our love of freedom, music and dance and our concern for the well-being of our neighbours . . . technology, one gets to know it somehow, even apes may be taught car-driving."

In the fifties, when négritude was in flower, the African writer abroad felt home-sick (as Camara Laye did at Paris, where he wrote his famous novel "L'enfant noir"). Yet, after returning home he soon became an alien among his own people - let us think of Achebe's Obi visiting his native village in Nigeria after having studied in England. Now, 
rather the contrary happens. Home-coming does not mean much difference any more to the African ex-city-dweller in Europe. For he, who may have been enticed, when abroad, by the sound of the imaginary drums, is welcomed home by the marks of civilisation,

\author{
"The mudwalls which knew his birth \\ Are gone... \\ There are no trees except electric \\ Lamp-poles and beacons all new, grey \\ And cold on cemented grey pavements ..."
}

as Femi Fatoba puts it in a poem recently published in "Journal of the New African Literature and the Arts" (New York.) Africa and Europe seem to have moved closer to each other, by the doubtful triumph of technology. But the nausea at civilisation is also part of the far reaching general disillusion of modern Africa. There is quite a distance from the literary optimism of the fifties in politics, technology and education to the resignation and disillusion felt in African writing of to-day.

\title{
WOMAN AUTHORS
}

Finally I would like to draw the attention to one more novelty in African literature, to the fact that more and more women start writing. Let us quickly view the main African authoresses. The first to my knowledge was the Ethiopian Romana Wärq Kasahun who wrote a play in 1950. Its title is "The light of science", which looks to me symptomatic of the strong will of African women to promote education. The next to follow was the South African Ntseliseng Masechele Khaketla from Lesotho, with another play, "The woman you gave me." In the sixties prose by Efua Sutherland (Ghana), Noni Jabavu (from the Ciskei), plays by Christina Ama Ata Aidoo (Ghana) and novels by the Ibo authoress Flora Nwapa and by Grace Ogot from Kenya, as well as less important works from Zaire (by Clementine Nzuji), Tansania (by Blandine Mhando) and Madagascar (by Clarisse Ratsifandrihamana) were published. Best known among these names are those of Ama Ata Aidoo and Flora Nwapa. These two African women writers have something in common too. Both Ama Ata Aidoo in her drama "Awowa" (1970) and Flora Nwapa in her novels show African women married to men of a spriritually and morally lower standard. 
Riches and power cannot equal manliness nor stand for the mental qualities of man. Riches may even destroy manliness. "A man", says Ama Ata Aidoo, "is judged by the quality of his soul". In both cases a highly talented African woman fulfills her vocation by serving a Goddess to whom she is magically bound and to whom she belongs by birth. In the motives of these two writers - the loneliness of the gifted woman and the insufficiency of material wealth to make for a happy marriage - I hear two ground notes which can already be recognised within the social political field of African literature: on the one hand the loneliness of the African intellectual, especially the writer himself, his aloofness from the people, his spiritual and social isolation, and on the other hand, more recent and more actual, the disillusion before the doubtful amenites of a materialistic civilisation.

\section{CONCLUSION}

I in no way want to belittle the differences existing throughout Africa and throughout African literature. I do not feel in line with any sort of panafricanism, not even a literary one. But I think we can see in the literary as in any other field of reality the unifying aspects beside the diversifying ones. The unifying facts in African literature are present in the subjects treated by writers of different regions in about the same way at various times. Speaking of subjects the main trends in African literature were: educational and religous motivation, predominating at the beginning of the century; furthermore culture-clash, with 'Jim goes to Jo'burg' and the like, a trend reaching its climax seemingly in the early sixties, and finally the scale of socio-political subjects, beginning with race conflicts and the antithesis of colonialism and uhuru, giving over now since the late sixties in combination with a revival of history, to the ever louder voice of political self-criticism. The melting pot which formed African literature into its present shape was clearly the impact of Christianity, of Western civilisation, of colonialism and decolonisation. The prevailing situation created hereby may change again, may even change to such a degree that it would make no sense any more to speak of African literature in a geographical way at all. The notion of African literature is, in my opinion, not abssiutely relevant. It depends on 
time and circumstances. It may expand or decrease or vanish altogether. For the time being and looking back upon some 100 years during which it developed to what it is to-day, we may rightly speak of "African literature" in the way I did.

\section{P Sulzer \\ Winterthur \\ Switzerland}

